First Smith's Prize in 1887. He held a fellowship at St. John's College from 1886 until 1899 and became a College lecturer (two of his colleagues being R. R. Webb and Sir Joseph Larmor). This was a time of great mathematical activity for Love, and he was elected fellow of the Royal Society in 1894. It was then, too, that there commenced his long association with the London Mathematical Society; besides filling the presidential office, he served for fifteen years as an honorary secretary, and was altogether thirty-three years on its Council.

Love was elected to the Sedleian chair in Oxford in 1899, and the increased leisure allowed him even to increase his research activity in his chosen subjects of elasticity, geodynamics and electrodynamics. $\mathrm{He}$ won the Adams Prize at Cambridge in 1911 for an essay entitled "Some Problems in Geodynamics", which was soon afterwards published. He was awarded a Royal Medal in 1909, the De Morgan Medal of the London Mathematical Society in 1926 and, as a fitting tribute to his life-long devotion to mathematics, the Royal Society's Sylvester Medal in 1937. He was elected an honorary fellow of St. John's College in 1927, in which year also he became a fellow of the Queen's College, Oxford. His international standing was recognized by his associateship of the Academy of the Lincei and his election as a corresponding member of the Institute of France.

Love will chiefly be remembered for two outstanding achievements, his discovery of what afterwards became known as 'Love waves' and his authorship of his treatise on the "Mathematical Theory of Elasticity". It is a classical result that any disturbance in an elastic medium resolves itself into the propagation of trains of compressional and distortional (equivoluminal) waves in three dimensions, but it is not immediately obvious that there exists a mode of combination of such trains which results in the propagation of a disturbance in two dimensions over the surface of a semi-infinite elastic body. Such a form of waves was discovered by Rayleigh. Love showed that in a medium consisting of a superficial layer of one density and rigidity resting on a subjacent layer of different density and rigidity, there exists a new form of two-dimensional waves, decreasing in amplitude exponentially with depth, propagating themselves with a tangential disturbance transverse to the direction of propagation, and depending for their existence essentially on the heterogeneity of the medium. These are of importance in seismology. Love investigated the dispersion of such wave-trains, and the application of his methods in the hands of seismologists has led to important information about the crust of the earth. The essay on geodynamics in which these investigations first appeared has a completeness of mathematical detail which makes it attractive reading to-day, and which contrasts strangely with the modern suppression of details of mathematical technique in physical papers which came in after the War of 1914-18, owing to the need for compression. Love's sentences-whether in English or in symbolism-come with the leisurely perfection of the great memoirs of a former century.
The treatise on the "Mathematical Theory of Elasticity" stands in a class with Lamb's "Hydrodynamics", and is a classic. If a comparison between 'good' things is at all legitimate, it may be said that Love's work is if anything the more scholarly but the tougher reading, as befitting a more intractable subject. Love was essentially a mathematician, delighting in partial differential equations and spherical harmonics; the eye to applications was there, but he was no engineer. The "Elasticity", like Lamb's "Hydrodynamics", is academic in character, but what a joy does the academic reader derive from it, once properly afloat on that inland sea! Whether it be the foundations of the subject, the equilibrium of strained bodies, the torsion of prisms, the vibration of solids, the propagation of waves, the bending of beams, or the theory of thin shells, the whole is verifiable, calm, controlled by the mind of a master. Love was perhaps attracted to the subject because after a controversial start it had settled down into a subject in which the principles were well accepted and well understood; the mathematician could, up to a point, have complete confidence in the foundation on which he was building.

Love's lectures at Oxford were ever models of form, and he devoted much care to the preparation of courses on subjects outside his researches-notably. on relativity and the tensor researches. In this connexion it is the more remarkable that in the "Elasticity" he scarcely recognizes that the components of strain on one hand and of stress on the other form tensors-three-dimensional symmetric tensors of a most instructive kind. His notation was in fact unfortunate, as it concealed the tensor nature of these entities; his $\mathrm{X} y$ and $\mathrm{Z} x$ for components of stress are quite frankly abominations of un-symmetricality, and his omission of the factor $\frac{1}{2}$ in his definitions of the non-principal components of strain is disastrous in transformation formulæ. But everything may be forgiven to a man of Love's attractive geniality and modesty of character.

It is not generally known that Love, in the War of 1914-18, made a contribution to ballistics which resulted in 'Love's method' for the calculation of trajectories being applied for some time at Woolwich. No notice of him would be complete without a mention of his hobby of eroquet. Oxford is the poorer by the loss of his characteristic figure on the croquet lawn in the parks.

E. A. Mrune.

\section{The Duke of Bedford, K.G., K.B.E., F.R.S.}

THE Duke of Bedford, who died on August 27 at the age of eighty-two, was elected to the Council of the Zoological Society of London in 1896. He was already known as an ardent and competent naturalist with a special interest in ducks, geese, cranes, gallinaceous birds, and herbivorous mammals. The foundation of his magnificent collection of animals at Woburn Park was already laid, and throughout his life he continued to improve it, spending large sums through the late Carl Hagenbeck and other collectors to add to its richness. He was not content 
with acquiring exotic animals; his great desire was to establish them and make breeding herds in Great Britain, and he acquired a unique knowledge of the conditions which made for success and failure. $\mathrm{He}$ was the first to introduce Prevalsky's wild horse to Europe. There is a small herd of the European bison, now extinct in its wild haunts, being nursed at Woburn, and he secured the last survivors of Père David's deer from the Royal Park at Pekin, so that there is at present in England the sole survivors of this unique species. Another accomplishment, very interesting to zoologists, is the successful acclimatization in the Woburn woods of the brush turkey.

On the Council of the Zoological Society, the Duke made the acquaintance of the late Mr. Oldfield Thomas, and began to subsidize collecting expeditions to Central Asia, Japan and China, with the result that the British Museum (Natural History) has an extraordinarily fine series of Chinese and Japanese mammals, including the types of many new species.

During his early years on the Council, the Duke, in his characteristically modest fashion, took little active part in its proceedings, but was a regular attendant and a shrewd observer. In 1899, on the death of Sir William Flower, he was elected president, a position which he held until he retired in 1936, and from then on, took a leading part in all the affairs of the Society. The great progress made during that time was due to his ready generosity, but still more to his wise but prudent counsel. On the resignation of P. L. Sclater, who had been secretary for many years, he appointed a special committee to examine the affairs of the Society and make plans for its reorganization. The control of the Council was made more direct; changes in staff and the allotment of duties were arranged. Financial control was strengthened; the general hygiene of the Gardens was vastly improved, and scientific investigation into the diseases and parasites affecting the animalssubjects in which the Duke took special interestwas arranged and provision for visitors was improved.

The financial position of the Society from increased numbers of fellows and of visitors quickly reacted to these changes, and it was possible to construct a large number of new buildings. The Duke was interested in all of them, but probably he was most deeply concerned with the Aquarium, and with the great experiment of Whipsnade. Jointly with the Fishmongers' Company he guaranteed an annual sinking fund to pay for the former, but fortunately the success was so great that the total cost was paid off from revenue in two years. Up to the last months of his life he took a deep interest in the progress of Whipsnade Park, remaining an honorary member of the Committee and visiting it frequently.

\section{P. Chalmers Mitchell.}

\section{Prof. A. D. Arkhangelsky}

THE death occurred in a sanatorium near Moscow, on June 16, at the age of sixty, of Andrei Dmitrievich Arkhangelsky, one of the foremost geologists of the U.S.S.R. Prof. Arkhangelsky's investigations of the geology of the U.S.S.R., based on a study of the laws of the geological development of the earth's crust, are of great theoretical and practical importance. His work has proved an accurate guide in the search for useful minerals.

Prof. Arkhangelsky is noted for his work on the tectonics of the Russian platform, which contributed so much to the discovery of the deposits of iron ore in the Kursk magnetic anomaly and the oil resources of the region lying between the Volga and the Urals, now come to be known as the "Second Baku". The expedition, led by him, of the Academy of Sciences of the U.S.S.R., which made a geological study of the European part of the U.S.S.R., applying geophysical methods to prospecting, laid down the lines of future prospecting for oil, coal and iron:

Prof. Arkhangelsky rendered valuable service to his country in the training of new geological personnel. From the early years of the Soviet regime he took an active part in the reform of higher education. For a considerable period he was professor in the Moscow Mining Academy, the University of Moscow and the Moscow Geological Prospecting Institute. His course on "Geology of the U.S.S.R." has become a standard work for every Soviet geologist.

Prof. Arkhangelsky was elected a member of the Academy of Sciences of the U.S.S.R. in 1925.

\section{Prof. S. Schönland}

The death on April 24, at the age of seventy-nine, of Prof. S. Schönland marks the passing of a botanist of international repute.

Educated at the Universities of Berlin and Kiel, Schönland as a young man was assistant to the professor of botany at Berlin and later at Oxford. $\mathrm{He}$ went to South Africa in 1889 and shortly after was appointed director of the Albany Museum. In 1904 he was appointed as the first professor of botany at Rhodes University College, a position he held until his resignation in 1925 .

His main interests lay in. systematic botany, to which he made many and valuable contributions. His botanical work, however, also extended over many other aspects; he published papers on plant distribution, ecology, biology, and practical problems such as weed eradication.

Schönland was much interested in education, and he played a big part in the building up of the University of South Africa and especially of Rhodes University College.

WE regret to announce the following deaths:

Sir Harold Carpenter, F.R.S., professor of metallurgy in the Royal School of Mines, Imperial College of Science and Technology, University of London, on September 13, aged sixty-five.

Prof. R. T. Hewlett, emeritus professor of bacteriology in the University of London, on September 10, aged seventy-five.

Miss E. L. Turner, the well-known field ornithologist, on August 13. 